\title{
Oral clonidine does not alter vecuronium neuromuscular blockade in anaesthetized patients
}

Since clonidine, an $\alpha_{Z}$-agonist, inhibits the release of norepinephrine or acetylcholine which can decrease nondepolarizing muscle relaxant-induced neuromuscular blockade, the authors examined whether clonidine given as an oral preanaesthetic medication would alter the onset, duration or recovery of a vecuronium neuromuscular blockade in lightly anaesthetized patients. Thirty-eight patients (aged 20-73 yr) randomly received oral clonidine either approximately $5 \mu \mathrm{g} \cdot \mathrm{kg}^{-1}(\mathrm{n}=$ 21 ) or none ( $n=17), 90$ min before arrival in the operating room. We measured acceleration of thumb contraction with ulnar nerve stimulation at the wrist to assess neuromuscular blockade. The onset time (the time from injection to decrease to $5 \%$ of baseline twitch height), duration (the time interval between injection and return of the first twitch to $25 \%$ of the baseline value), and recovery index (the time interval of the first twitch from $25 \%$ to $75 \%$ of the baseline value) of neuromuscular blockade from a single bolus of vecuronium 0.1 $m g \cdot \mathrm{kg}^{-1}$ in were determined and compared between the clonidine-treated and control patients during lower abdominal or extremity surgery under epidural plus general anaesthesia with fentanyl and nitrous oxide in oxygen. No differences were noted between the control and clonidine groups in onset time $(100 \pm 6 \mathrm{sec}$ (mean $\pm S E)$ vs $101 \pm 6 \mathrm{sec}$ ), duration (44.5

\section{Key words}

NEUROMUSCULAR BLOCKADE: onset time, duration, recovery index;

NEUROMUSCULAR RELAXANTS: vecuronium;

SYMPATHETIC NERVOUS SYSTEM: $\alpha_{2}$-adrenergic agonists, clonidine.

From the Department of Anaesthesiology, Institute of Clinical Medicine, University of Tsukuba, Tsukuba City, Ibaraki 305, Japan.

Address correspondence to: Dr. Toshiaki Nishikawa,

Department of Anaesthesiology, Institute of Clinical Medicine, University of Tsukuba, Tsukuba City, Ibaraki 305, Japan. Accepted for publication 10th February, 1995. $\pm 2.7 \mathrm{~min} v \mathrm{~s} 42.9 \pm 2.7 \mathrm{~min}$ ), or recovery index (21.6 \pm 2.8 min vs $19.1 \pm 1.9 \mathrm{~min}$ ) of neuromuscular blockade from vecuronium, respectively. These results show that oral preanaesthetic medication of clonidine $5 \mu \mathrm{g} \cdot \mathrm{kg}^{-1}$ does not alter neuromuscular blockade induced with vecuronium $0.1 \mathrm{mg} \cdot \mathrm{kg}^{-1}$ in patients during combined epidural and fentanyl/nitrous oxide general anaesthesia.

La clonidine, un $\alpha_{Z}$-agoniste, inhibe la libération de norépinéphrine et de l'acétylcholine; elle peut donc diminuer la curarisation induite par un myorelaxant non dépolarisant. Nous nous sommes demandés si la clonidine administrée en prémédication pouvait altéter l'installation, la durée et la récupération de la curarisation produites par le vécuronium chez dez patients maintenus sous anesthése légère. Trente-huit patients (âgés de 20 à 73 ans) sont choisis au hasard pour recevoir soit de la clonidine orale à la dose approximative de $5 \mu \mathrm{g} \cdot \mathrm{kg}^{-1}(\mathrm{n}=$ 21) soit un placebo $(n=17), 90$ min avant leur transfert en salle d'opération. Pour évaluer la curarisation, nous mesurons au niveau du poignet, l'accélération de la contraction du pouce en stimulant le nerf cubital. L'installaion (lintervalle entre linjection à la diminution à $5 \%$ de la ligne de basse de la hauteur du twitch) et lindice de récupération (intervalle requis pour le retour du premier witch de 25 à $75 \%$ de sa valeur initiale) du bloc neuromusculaire sont déterminés après l'administration en bolus unique du vécuronium, $0,1 \mathrm{mg} \cdot \mathrm{kg}^{-1}$ iv. Les mesures sont comparées entre le groupe traité à la clonidine et le groupe contrôle pendant une chirurgie abdominale basse ou une chirurgie des extrémités. Une anesthésie épidurale èst complétée par une anesthésie générale au fentanyl et au protoxyde d'azoteoxygène. Nous ne constatons pas de différence entre le groupe contrôle et le groupe clonidine au regard de linstallation (100 $\pm 6 \mathrm{sec}$ (moyenne $\pm S E$ ) vs $101 \pm 6 \mathrm{sec}$ ), la durée $(44,5 \pm$ 2,7 min vs 42,9 $\pm 2,7 \mathrm{~min}$ ) et de l'indice de récupération (21,6 $\pm 2,8 \mathrm{~min}$ vs $19,1 \pm 1,9 \mathrm{~min}$ ). Ces résultats démontrent que la prémédication orale à la clonidine, $5 \mu \mathrm{g} \cdot \mathrm{kg}^{-1}$, náltère en aucune façon la curarisation induite par le vécuronium, 0,1 $m g \cdot k g^{-1}$, chez les patients qui reçoivent une anesthésie épidurale complétée par une générale au fentanyl-protoxyde d'azote. 
Although oral clonidine was originally used as preanaesthetic medication to reduce opioid or volatile anaesthetic requirements and to improve cardiovascular stability, ${ }^{1-4}$ it has recently been demonstrated to possess several unique effects such as altered responses to ephedrine or atropine, ${ }^{5,6}$ and diuresis ${ }^{7}$ in humans. For clinical anaesthesia, vecuronium is one of the most frequently used nondepolarizing muscle relaxants, because of its relatively short duration of action, minimal cardiovascular effects, and no apparent histamine releasing properties. ${ }^{8}$ However, there are no clinical reports concerning the effect of clonidine on neuromuscular blockade from a nondepolarizing muscle relaxant. ${ }^{9}$

Clonidine is known to inhibit norepinephrine release from sympathetic nerve terminals and thus decrease the plasma concentration of norepinephrine, ${ }^{4,10-13}$ while several previous animal experiments have demonstrated that intraarterially or intravenously administered catecholamines possessing $\alpha$-adrenoceptor stimulant properties (norepinephrine or epinephrine) reversed d-tubocurarineinduced neuromuscular blockade or exerted a facilitatory action on neuromuscular transmission through actions at prejunctional sites; i.e., by enhancing release of acetylcholine in skeletal muscle. ${ }^{14-17}$ Also, stimulation of presynaptic $\alpha_{2}$-adrenoceptors has been reported to inhibit the release of acetylcholine in the central nervous system. ${ }^{18}$ It is therefore assumed that the neuromuscular blocking action of a nondepolarizing muscle relaxant may be potentiated in patients receiving clonidine.

However, there is no clinical information regarding the interaction between clonidine and vecuronium in humans. ${ }^{9}$ Furthermore, there is no evidence that $\alpha_{2}$ adrenoceptors are present on either the motor neuron or the endplate. ${ }^{9}$ The aim of this study was to determine whether preanaesthetic oral clonidine medication would affect the neuromuscular blockade produced by vecuronium.

\footnotetext{
Methods

Thirty-eight adult patients, ranging in age from 20 to $73 \mathrm{yr}$, ASA physical status 1 or 2 , gave informed consent to participate in research approved by Human Investigation Committee at the University of Tsukuba Hospital. The patients scheduled for elective lower abdominal or lower extremity surgery were included. No patients had any cardiopulmonary, renal, hepatic or neuromuscular disorders, or marked obesity exceeding standard body weight by $20 \%$ or more. Patients had not received drugs such as aminoglycoside antibiotics, antihistamines or opioids, nor had taken alcohol or nicotine within $48 \mathrm{hr}$ preceding the study. Patients with diabetes mellitus, serum electrolyte abnormalities, anaemia, and sinus bradycardia (heart rate $<60$ beats $\cdot \mathrm{min}^{-1}$ ), were excluded.
}

Each patient was randomly assigned to one of two groups. The patients received either oral clonidine 5 $\mu \mathrm{g} \cdot \mathrm{kg}^{-1}$ (clonidine group; $n=21$ ) or none (control group; $n=17$ ) $90 \mathrm{~min}$ before arrival in the operating room. Because clonidine (Catapres ${ }^{\circledR}$, Boehringer Ingelheim \& Tanabe) is available only in tablets of $75 \mu \mathrm{g}$ or $150 \mu \mathrm{g}$ in Japan, the doses of clonidine were determined by choosing the closest doses calculated by multiplying $37.5 \mu \mathrm{g}$ (half a tablet) as a unit. After an ECG, automatic blood pressure cuff (Listmini(i), Nippon Colin Co., Ltd., Tokyo) and pulse oximeter were established, a $16 \mathrm{G}$ cannula was placed into the forearm cutaneous vein. Lactated Ringer's solution was thereafter infused through the $i v$ cannula at an approximate rate of 10 $\mathrm{ml} \cdot \mathrm{kg}^{-1} \cdot \mathrm{hr}^{-1}$ until the end of anaesthesia.

After patients were placed in the lateral ducubitus position, the skin of the lumbar region was prepared with antiseptic solution and draped, and local infiltration was carried out using $5 \mathrm{ml}$ lidocaine $0.5 \%$ intradermally and subcutaneously at $\mathrm{L}_{2-3}$ or $\mathrm{L}_{3-4}$ intervertebral space. A 16-gauge Tuohy needle was then introduced into the epidural space using the balloon technique. Following the identification of the epidural space, an epidural catheter was advanced cephalad approximately $4-5 \mathrm{~cm}$ into the epidural space. Then, the patient was placed supine. Epidural anaesthesia was produced by injection through the epidural catheter $13 \mathrm{ml}$ lidocaine $1.5 \%$ solution with $1: 200,000$ epinephrine. The analgesic level was confirmed with pinprick at ten minutes after the epidural injection of lidocaine.

A $5 \times 10 \mathrm{~mm}$ plastic-coated acceleration transducer (Biometer, Denmark) which contains a piezo-electric ceramic wafer, was fastened to the volar side of interphalangeal joint of the thumb by means of a piece of adhesive tape. Free movement during evoked thumb adduction was allowed by fixation of the extended four ulnar fingers and by an elastic band lightly separating the thumb from the index finger. General anaesthesia was induced with thiamylal approximately $5 \mathrm{mg} \cdot \mathrm{kg}^{-1}$ plus fentanyl $150-300 \mu \mathrm{g} \dot{\mathrm{N}}$, and maintained with nitrous oxide $67 \%$ in oxygen. Single supramaximal electrical stimuli $(1 \mathrm{~Hz})$ were applied to the ulnar nerve at the wrist using surface electrodes (Myotest $(\mathrm{IO}$, Biometer, Denmark), while acceleration of the thumb was recorded by the acceleration transducer for three minutes before administration of vecuronium to establish a stable baseline value. The resulting electrical signal was passed through a converter and analyzed by a Myograph 2000 (Bi) (Biometer, Denmark) monitoring unit for immediate display and recording of neuromuscular transmission values. ${ }^{19}$ Vecuronium $0.1 \mathrm{mg} \cdot \mathrm{kg}^{-1}\left(1 \mathrm{mg} \cdot \mathrm{ml}^{-1}\right)$ was injected over two seconds into a rapidly running intravenous infusion through a T-port located at the catheter. The time from vecuronium 
injection to decrease of twitch to $5 \%$ of the baseline value was taken as the onset time. Three minutes later, tracheal intubation was performed without use of other adjuvants. The single twitch stimulation $(1 \mathrm{~Hz})$ was changed to trainof-four stimulation ( $2 \mathrm{~Hz}$ for $2 \mathrm{sec}$ at 12 sec-intervals) five minutes after tracheal intubation. The proposed surgery was started approximately $20 \mathrm{~min}$ after induction of general anaesthesia. Neuromuscular function was allowed to recover spontaneously. The interval between vecuronium injection and return of the first twitch $\left(T_{1}\right)$ to $25 \%$ of the baseline value, and the interval of $T_{1}$ from $25 \%$ to $75 \%$ of the baseline value were recorded as the clinical duration of neuromuscular blockade and recovery index, respectively.

During the study, measurements of blood pressure and heart rate were made at one-minute intervals. A rectal temperature probe (Model 47559, NEC San-ei Instrument Co., Ltd., Tokyo) was placed after the induction of general anaesthesia, and maintained within $1.0^{\circ} \mathrm{C}$ of the baseline value (the value just at the beginning of measurement). The lungs were mechanically ventilated to maintain end-tidal carbon dioxide tension between 30 and $40 \mathrm{mmHg}$. Hypotension (defined as systolic blood pressure $<80 \mathrm{mmHg}$ ) and bradycardia (defined as heart rate $<50$ beats $\cdot \mathrm{min}^{-1}$ ) were treated with ephedrine 0.1 $\mathrm{mg} \cdot \mathrm{kg}^{-1}$ and atropine $0.01 \mathrm{mg} \cdot \mathrm{kg}^{-1} \dot{N}$, respectively. At the end of surgery, the residual neuromuscular blockade was antagonized with neostigmine $0.05 \mathrm{mg} \cdot \mathrm{kg}^{-1}$ and atroine $0.02 \mathrm{mg} \cdot \mathrm{kg}^{-1} \dot{w}$.

We sampled arterial blood during the study. Plasma electrolyte concentrations and blood gas tensions were determined with a multichannel electrolyte analyzer (NOVA 6@i); Nova, Massachusetts) and $\mathrm{pH} /$ blood gas analyzer (Corning 178(i); Corning, Medfield, Massachusetts), respectively. Results were reported as means $\pm S E$. Sex ratio and incidence of hypotension or bradycardia between groups were examined by chi-squared analysis. Comparisons of other data between groups were performed by unpaired Student's t test. A $P$ value $<0.05$ was considered significant.

\section{Results}

There were no differences between groups in demographic, arterial blood gas, and plasma electrolytes data (Table I). The clonidine dose administered was $4.98 \pm$ $0.07 \mu \mathrm{g} \cdot \mathrm{kg}^{-1}$. The interval from epidural injection of lidocaine to vecuronium administration was similar between groups ( $931 \pm 16$ and $932 \pm 14 \mathrm{sec}$ in the control and clonidine groups, respectively). Five patients in the control group and 17 in the clonidine group received ephedrine for the treatment of hypotension, while one patient in the control group and ten patients in the clonidine group received atropine for the treatment of bra-
TABLE I Demographic, laboratory and treatment data of the patients

\begin{tabular}{lcc}
\hline & $\begin{array}{c}\text { Control group } \\
(n=17)\end{array}$ & $\begin{array}{c}\text { Clonidine group } \\
(n=21)\end{array}$ \\
\hline Gender (male/female) & $0 / 17$ & $4 / 17$ \\
Age $(\mathrm{rr})$ & $49 \pm 4$ & $46 \pm 3$ \\
Weight $(\mathrm{kg})$ & $55 \pm 2$ & $52 \pm 2$ \\
$\mathrm{Clonidine}\left(\mu \mathrm{g} \cdot \mathrm{kg}^{-1}\right)$ & - & $4.98 \pm 0.07$ \\
$\mathrm{pHa}$ & $7.45 \pm 0.01$ & $7.41 \pm 0.01$ \\
$\mathrm{PaCO}_{2}(\mathrm{mmHg})$ & $34 \pm 1$ & $35 \pm 1$ \\
$\mathrm{PaO}_{2}(\mathrm{mmHg})$ & $140 \pm 8$ & $139 \pm 8$ \\
$\mathrm{Base} \mathrm{excess}\left(\mathrm{mEq} \cdot \mathrm{L}^{-1}\right)$ & $0.4 \pm 0.6$ & $1.0 \pm 0.4$ \\
Plasma sodium $\left(\mathrm{mEq} \cdot \mathrm{L}^{-1}\right)$ & $143 \pm 1$ & $142 \pm 1$ \\
Plasma potassium $\left(\mathrm{mEq} \cdot \mathrm{L}^{-1}\right)$ & $3.3 \pm 0.1$ & $3.6 \pm 0.1$ \\
Plasma ionized calcium $\left(\mathrm{mEq} \cdot \mathrm{L}^{-1}\right)$ & $0.93 \pm 0.02$ & $0.97 \pm 0.02$ \\
Total dose of fentanyl $(\mu \mathrm{g})$ & $121 \pm 6$ & $121 \pm 7$ \\
Number of patients given ephedrine & $5 / 17(29 \%)$ & $17 / 21(81 \%)^{*}$ \\
Total dose of ephedrine $(\mathrm{mg})$ & $2.4 \pm 1.0$ & $6.4 \pm 1.4^{*}$ \\
Number of patients given atropine & $1 / 17(6 \%)$ & $10 / 21(48 \%)^{*}$ \\
Total dose of atropine $(\mathrm{mg})$ & $0.03 \pm 0.03$ & $0.23 \pm 0.06^{*}$ \\
\hline
\end{tabular}

Values are mean $\pm \mathrm{SE}$

$* P<0.05$ versus control group.

TABLE II Onset time, duration, and recovery index of neuromuscular blockade produced by a bolus dose of vecuronium 0.1 $\mathrm{mg} \cdot \mathrm{kg}^{-1}$

\begin{tabular}{lcc}
\hline & $\begin{array}{l}\text { Control group } \\
(n=17)\end{array}$ & $\begin{array}{l}\text { Clonidine group } \\
(n=21)\end{array}$ \\
\hline Onset time (sec) & $100 \pm 6(64-166)$ & $101 \pm 6(70-170)$ \\
Duration (min) & $44.5 \pm 2.7(25.5-61.3)$ & $42.9 \pm 2.7(26.3-71.6)$ \\
Recovery index (min) & $21.6 \pm 2.8(10.8-52.7)$ & $19.1 \pm 1.9(7.3-37.4)$ \\
\hline
\end{tabular}

Values are mean \pm SE (ranges).

dycardia $(P<0.05$, Table I). The mean total doses of ephedrine and atropine for the treatments of hypotension and bradycardia, respectively, were larger in the clonidine group than the control group $(P<0.05)$. All of the patients responded well to these treatments.

No differences were noted in the onset time, duration or recovery index of neuromuscular blockade with a single dose of vecuronium $0.1 \mathrm{mg} \cdot \mathrm{kg}^{-1}$ between the two groups (Table II). Also, there were no differences in these variables between patients with and without ephedrine treatment, and between patients with and without atropine treatment in both groups. In addition, no patient in the clonidine group showed abnormal responses to vecuronium such as rapid onset of neuromuscular blockade or prolonged neuromuscular blockade resistant to neostigmine.

\section{Discussion}

This study showed that preanaesthetic oral clonidine medication approximately $5 \mu \mathrm{g} \cdot \mathrm{kg}^{-1}$ did not alter the onset 
time, duration or recovery index of neuromuscular blockade produced by a single dose of vecuonium $0.1 \mathrm{mg} \cdot \mathrm{kg}^{-1}$ $i v$ in patients during combined epidural and general anaesthesia.

Experimentally, norepinephrine or epinephrine have been reported to antagonize the neuromuscular blockade from tubocurarine, or facilitate neuromuscular transmission possibly through enhancing acetylcholine release from prejunctional sites in skeletal muscle. ${ }^{14-17}$ Both plasma catecholamine concentrations and acetylcholine release, in turn, are suppressed by clonidine $.^{4,10-13,18} \mathrm{Be}-$ cause we did not measure plasma catecholamine concentrations in this study, it is uncertain whether they were within the same range in both groups. Alternatively, reversal of neuromuscular blockade by $\alpha_{2}$-adrenoceptor agonists per $s e^{15}$ might have masked the enhancement of vecuronium neuromuscular blockade via suppression of catecholamine and acetylcholine release by clonidine. However, the large doses of ephedrine and atropine administered during the study seemed to have no influence on the neuromuscular blockade from vecuronium, since there was no difference in any monitored variables of vecuronium neuromuscular blockade between the patients with and without these treatments in each group. It is also uncertain whether cardiac output and muscle blood flow, primary determinants for the speed of onset of a muscle relaxant, ${ }^{20,21}$ were different between the two groups in this study, because there were no measurements of these variables. However, large differences in these variables are unlikely to have occurred in subjects receiving clonidine, since it has been reported that clonidine 5 $\mu \mathrm{g} \cdot \mathrm{kg}^{-1}$ does not change cardiac output. ${ }^{1,22}$

The liver is a major organ for elimination of vecuronium bromide. $23-26$ Since clonidine is reported to decrease hepatic elimination in rats, ${ }^{27}$ clonidine may delay the recovery of neuromuscular blockade by vecuronium. However, based on the current results that clonidine 5 $\mu \mathrm{g} \cdot \mathrm{kg}^{-1}$ affected neither the duration nor recovery index of neuromuscular blockade from vecuronium 0.1 $\mathrm{mg} \cdot \mathrm{kg}^{-1}$, this dose of clonidine does not seem to alter the elimination of vecuronium in healthy patients. Nevertheless, we cannot exclude the possibility of clonidineinduced alteration in neuromuscular blockade, because sample size was quite small. To confirm that there is no clinically relevant interaction between clonidine and vecuronium, further study is needed to measure the neuromuscular blocking action of vecuronium when used in repeated or large doses, especially in patients with liver dysfunction.

Most local anaesthetics potentiate neuromuscular blockade from nondepolarizing muscle relaxants. ${ }^{28,29}$ However, it is likely that both plasma concentration of lidocaine and the effect of lidocaine on neuromuscular blockade were comparable to both groups in this study, because there was no difference in the time interval from epidural injection of lidocaine to administration of vecuronium between groups, and oral clonidine $5 \mu \mathrm{g} \cdot \mathrm{kg}^{-1}$ did not reduce the elimination of epidurally administered lidocaine. ${ }^{30}$ We used an acceleration transducer in our study, since there is good correlation between the values measured by an acceleration transducer and by a forcedisplacement transducer, ${ }^{31-33}$ and the precision of both methods seems to be comparable..$^{34}$

In conclusion, our study suggests that oral clonidine premedication of $5 \mu \mathrm{g} \cdot \mathrm{kg}^{-1}$ does not alter the onset, duration or recovery of neuromuscular blockade from a dose of vecuronium $0.1 \mathrm{mg} \cdot \mathrm{kg}^{-1} \dot{\boldsymbol{N}}$ during combined epidural and light general anaesthesia.

\section{Acknowledgments}

The authors wish to thank Drs. S. Kihara, S. Yamamoto, S. Yamashita, M. Kumagai, H. Nakayama, T. Satsumae, A. Suga, Senior Residents in the Department of Anaesthesia, University of Tsukuba Hospital, for their help in performing the study.

\section{References}

1 Ghignone M, Quintin L, Duke PC, Kehler CH, Calvillo $O$. Effects of clonidine on narcotic requirements and hemodynamic response during induction of fentanyl anesthesia and endotracheal intubation. Anesthesiology 1986; 64: 36-42.

2 Ghignone $M$, Calvillo $O$, Quintin L. Anesthesia and hypertension: the effect of clonidine on perioperative hemodynamics and isoflurane requirements. Anesthesiology 1987; 67: 3-10.

3 Ghignone $M$, Noe $C$, Calvillo $O$, Quintin L. Anesthesia for ophthalmic surgery in the elderly: the effects of clonidine on intraocular pressure, perioperative hemodynamics, and anesthetic requirement. Anesthesiology 1988; 68: 707-16.

4 Flacke JW, Bloor BC, Flacke WE, et al. Reduced narcotic requirement by clonidine with improved hemodynamic and adrenergic stability in patients undergoing coronary bypass surgery. Anesthesiology 1987; 67: 11-9.

5 Nishikawa T, Kimura T, Taguchi N, Dohi S. Oral clonidine preanesthetic medication augments the pressor responses to intravenous ephedrine in awake or anesthetized patients. Anesthesiology 1991; 74: 705-10.

6 Nishikawa $T$, Dohi $S$. Oral clonidine blunts the heart rate response to intravenous atropine in humans. Anesthesiology 1991; 75: 217-22.

7 Hamaya Y, Nishikawa T, Dohi S. Diuretic effect of clonidine during isoflurane, nitrous oxide, and oxygen anesthesia. Anesthesiology 1994; 81: 811-9.

8 Morris RB, Cahalan MK, Miller RD, Wilkinson PL, Qua- 
sha $A L$, Robinson $S L$. The cardiovascular effects of vecuronium (ORG 45) and pancuronium in patients undergoing coronary artery bypass grafting. Anesthesiology 1983; 58: $438-40$.

9 Salonen MA, Kanto JH, Maze M. Clinical interactions with alpha-2-adrenergic agonists in anesthesia practice. $\mathbf{J}$ Clin Anesth 1992; 4: 164-72.

10 Veith RC, Best JD, Halter JB. Dose-dependent suppression of norepinephrine appearance rate in plasma by clonidine in man. J Clin Endocrinol Metab 1984; 59: 151-5.

11 Kooner JS, Birch R, Frankel HL, Peart WS, Mathias CJ. Hemodynamic and neurohormonal effects of clonidine in patients with preganglionic and postganglionic sympathetic lesions: evidence for a central sympathetic action. Circulation 1991; 84: 75-83.

12 Pouttu J, Scheinin B, Rosenberg PH, Viiamäki O, Schei$\operatorname{nin} M$. Oral premedication with clonidine: effects on stress responses during general anaesthesia. Acta Anaesthesiol Scand 1987; 31: 730-4.

13 Pouttu J, Ttominen M, Scheinin M, Rosenberg PH. Effects of oral clonidine premedication on concentrations of cortisol and monoamine neurotransmitters and their metabolites in cerebrospinal fluid and plasma. Acta Anaesthesiol Scand 1989; 33: 137-41.

14 Bowman WC, Raper C. Effects of sympathomimetic amines on neuromuscular transmission. British Journal Pharmacology Chemotherapy 1966; 27: 313-31.

15 Malta E, McPherson GA, Raper C. Comparison of prejunctional $\alpha$-adrenoceptors at the neuromuscular junction with vascular post-junctional $\alpha$-receptors in cat skeletal muscle. Br J Pharmacol 1979; 65: 249-56.

16 Bowman WC, Zaimis E. The effects of adrenaline, noradrenaline and isoprenaline on skeletal muscle contractions in the cat. J Physiol 1958; 144: 92-107.

$17 K u b a K$. Effects of catecholamines on the neuromuscular junction in the rat diaphragm. J Physiol 1970; 211: 551-70.

18 Dubocovich $M L$. Presynaptic alpha-adrenoceptors in the central nervous system. Ann NY Acad Sci 1984; 430: 7-25.

19 Viby-Mogensen J. Clinical assessment of neuromuscular transmission. Br J Anaesth 1982; 54: 209-23.

20 Harrison $G A$, Junius $F$. The effect of circulation time on the neuromuscular action of suxamethonium. Anaesth Intensive Care 1972; 1: 33-40.

21 Donati $F$. Onset of action of relaxants. Can J Anaesth 1988; 35: S52-8.

22 Engelman E, Lipszyc $M$, Gilbart E, et al. Effects of clonidine on anesthetic drug requirements and hemodynamic response during aortic surgery. Anesthesiology 1989; 71: 178-87.

23 Bencini AF, Scaf AHJ, Sohn YJ, Kersten-Kleef UW, Agoston $S$. Hepatobiliary disposition of vecuronium bromide in man. Br J Anaesth 1986; 58: 988-95.

24 Bencini AF, Mol WEM, Scaf AHJ, et al. Uptake and excretion of vecuronium bromide and pancuronium bromide in the isolated perfused rat liver. Anesthesiology 1988; 69: 487-92.

25 Upton RA, Nguyen $T-L$, Miller RD, Castagnoli $N$ Jr. Renal and biliary elimination of vecuronium (Org NC 45) and pancuronium in rats. Anesth Analg 1982; 61: 313-6.

26 Lebrault $C$, Berger $J L, D^{\prime} H o l l a n d e r ~ A A$, Gomeni $R$, Henzel D, Duvaldestin P. Pharmacokinetics and pharmacodynamics of vecuronium (ORG NC 45) in patients with cirrhosis. Anesthesiology 1985; 62: 601-5.

27 Ben-Zvi Z, Hurwitz A. Clonidine effects on disposition of xenobiotics in rats: inhibited elimination of flow-limited but not extraction-limited agents. Br J Pharmacol 1988; 94: 97-102.

28 Usubiaga JE, Wikinski JA, Morales RL, Usubiaga LEJ. Interaction of intravenously administered procaine, lidocaine and succinylcholine in anesthetized subjects. Anesth Analg 1967; 46: 39-45.

29 Telivuo $L$, Katz $R L$. The effects of modern intravenous local analgesics on respiration during partial neuromuscular block in man. Anaesthesia 1970; 25: 30-5.

30 Nishikawa T, Goyagi T, Kimura T, Dai M, Naito H. Oral clonidine preanaesthetic medication does not alter plasma lidocaine elimination during epidural anaesthesia in lightly anaesthetized patients (Letter). Can J Anaesth 1992; 39: 521-2.

31 Viby-Mogensen J, Jensen E, Werner M, Nielsen HK. Measurement of acceleration: a new method of monitoring neuromuscular function. Acta Anaesthesiol Scand 1988; 32 45-8.

32 Jensen E, Viby-Mogensen J, Bang U. The Accelograph ${ }^{\circledR}$ : a new neuromuscular transmission monitor. Acta Anaesthesiol Scand 1988; 32: 49-52.

33 Werner $M U$, Nielsen $H K$, May $O$, Djernes $M$. Assessment of neuromuscular transmission by the evoked acceleration response: an evaluation of the accuracy of the acceleration transducer in comparison with a force displacement transducer. Acta Anaesthesiol Scand 1988; 32: 395-400.

34 May $O$, Kirkegaard Neilsen H, Werner MU. The acceleration transducer - an assessment of its precision in comparison with a force displacement transducer. Acta Anaesthesiol Scand 1988; 32: 239-43. 